\title{
Climate factors influence the occurrence of white spot disease in cultured penaeid shrimp in Chanthaburi province, Thailand
}

\author{
Patharapol Piamsomboon ${ }^{1}$, Chaidate Inchaisri ${ }^{2}$, Janenuj Wongtavatchai $^{1, *}$ \\ ${ }^{1}$ Department of Veterinary Medicine, Faculty of Veterinary Science, Chulalongkorn University, Pathumwan, Bangkok 10330, \\ Thailand \\ ${ }^{2}$ Epidemiology and Animal Health Economics Group, Department of Veterinary Medicine, Faculty of Veterinary Science, \\ Chulalongkorn University, Pathumwan, Bangkok 10330, Thailand
}

\begin{abstract}
This study investigated the prevalence of white spot disease (WSD) in an intensive shrimp culture area located in Chanthaburi province, Thailand, during 2009-2014. Retrospective data of 1952 WSD cases obtained from government laboratories were analyzed to study the association between WSD occurrence and climate factors using negative binomial regression (NBR) models. Climate factors included daily atmospheric temperature, relative humidity, wind speed, total amount of rainfall and rain days during the disease notifications. The annual prevalence of WSD was significantly higher from 2009 to 2011 than from 2012 to 2014. Interestingly, the monthly WSD occurrence was unchanged between those time periods. A high number of WSD cases was found between October and February, while fewer cases were reported during March to June, and the lowest numbers were reported in May. The multivariate NBR model indicated significant associations between an increased number of WSD cases with decreased atmospheric temperature and increased variation in daily atmospheric temperature. A high incident rate ratio (IRR) of WSD was observed when average atmospheric temperature ranged between 24.5 and $27.2^{\circ} \mathrm{C}$ (IRR: $2.53,95 \%$ CI: 1.72-3.75) and there was increased variation in daily atmospheric temperature (IRR: 1.08 , 95\% CI: 0.99-1.20). The time series analysis concluded that low ambient atmospheric temperature and high daily atmospheric temperature variation were promoting factors for WSD occurrence.
\end{abstract}

KEY WORDS: White spot disease $\cdot$ Prevalence $\cdot$ Atmospheric temperature $\cdot$ Negative binomial regression

\section{INTRODUCTION}

White spot disease (WSD) is caused by an infection of white spot syndrome virus (WSSV), a circular double-stranded DNA virus in the family Nimaviridae (van Hulten et al. 2001). Moribund shrimp commonly have pinkish to reddish discoloration with or without various sizes of white inclusion under the outer exoskeleton (OIE 2015). Mortality rate can reach $100 \%$ within 3-10 d of the appearance of the symp-

\footnotetext{
${ }^{*}$ Corresponding author: janenuj.w@chula.ac.th
}

tom (Hossain et al. 2015). Previous studies have indicated that season and atmospheric conditions such as temperature and rainfall are important factors causing WSD. WSD in Ecuadorian Pacific white shrimp Litopenaeus vannamei farms evidently occurred during the dry/cool season in June to November (Rodríguez et al. 2003). In the Philippines, the prevalence of WSSV-positive wild-captured black tiger shrimp Penaeus monodon increased in the hot/dry season from April to May (de la Peña et al. 2007), and

(C) The authors 2016. Open Access under Creative Commons by Attribution Licence. Use, distribution and reproduction are unrestricted. Authors and original publication must be credited. 
increased WSD outbreaks in pond-cultured P. monodon were found in one month with $>14$ continuous rain days (Tendencia et al. 2010). High prevalence of WSSV in wild-captured P. monodon was also reported in the cool-monsoon season from June to November in Thailand (Withyachumnarnkul et al. 2003) and from April to August in Bangladesh (Iqbal et al. 2011).

Shrimp production in Thailand has been adversely affected by WSD since 1995 (Flegel 1997). To reduce the risk of transmitting WSD from a wild population, penaeid shrimp production has shifted from wild-captured P. monodon to domesticated $L$. vannamei brood-stock, beginning decades ago. However, WSD still causes significant losses in $L$. vannamei culture (Flegel 2012). Although it has been observed that shrimp farmers in Thailand avoid stocking shrimp during the low-temperature season because they have experienced dramatic loss caused by WSD, the impact of climate factors on WSD in penaeid shrimp production in Thailand has never been addressed.

This present study investigated WSD prevalence and the association between WSD occurrence and climate factors in an intensive shrimp culture area of Thailand between 2009 and 2014. This information can be used to help minimize the risk of WSD in outdoor shrimp culture.

\section{MATERIALS AND METHODS}

\section{Study area}

The studied area was located in Chanthaburi province in the eastern part of Thailand (Fig. 1). Chanthaburi is one of the largest shrimp grow-out areas in Thailand, expanding from 3900 ha in 2009 to 6800 ha culture area in 2012. Shrimp production in this area performed regularly throughout the year. Its annual production yield is more than $60000 \mathrm{t}$, and $98 \%$ of the cultured shrimp is Litopenaeus vannamei (Department of Fisheries 2014). Three seasons are described in this area: rainy season, from mid-May to mid-October; cool season, from mid-October to midFebruary; and warm season, from mid-February to mid-May.

\section{Laboratory data and WSD prevalence}

Laboratory data of WSD diagnosis between 2009 and 2014 were retrieved from government research centers (Department of Fisheries, Ministry of Agriculture and Cooperative). The centers provide shrimpdisease diagnostic services to local shrimp farmers in the region. A WSD case was confirmed when the diseased shrimp tested positive for WSSV in a singlestep PCR (OIE 2015). Data included in the study were of pond-cultured shrimp, from the $10 \mathrm{~d}$ post larval stage onwards. Positive samples from the same pond were counted as a single occurrence. Prevalence of WSD was calculated by dividing the number of positive samples by the total number of submitted samples and was reported on a monthly and yearly basis.

\section{Climate data}

Meteorological data in the study area were provided by the Meteorological Department of Thailand, Ministry of Information and Communication Technology. Data were recoded every $3 \mathrm{~h}$ and averaged for daily atmospheric temperature, relative humidity, wind speed and total amount of rainfall. Daily atmospheric temperature variation was computed from the differences between minimum and maximum atmospheric temperature. Descriptive statistics were used to aggregate the data into monthly averages.

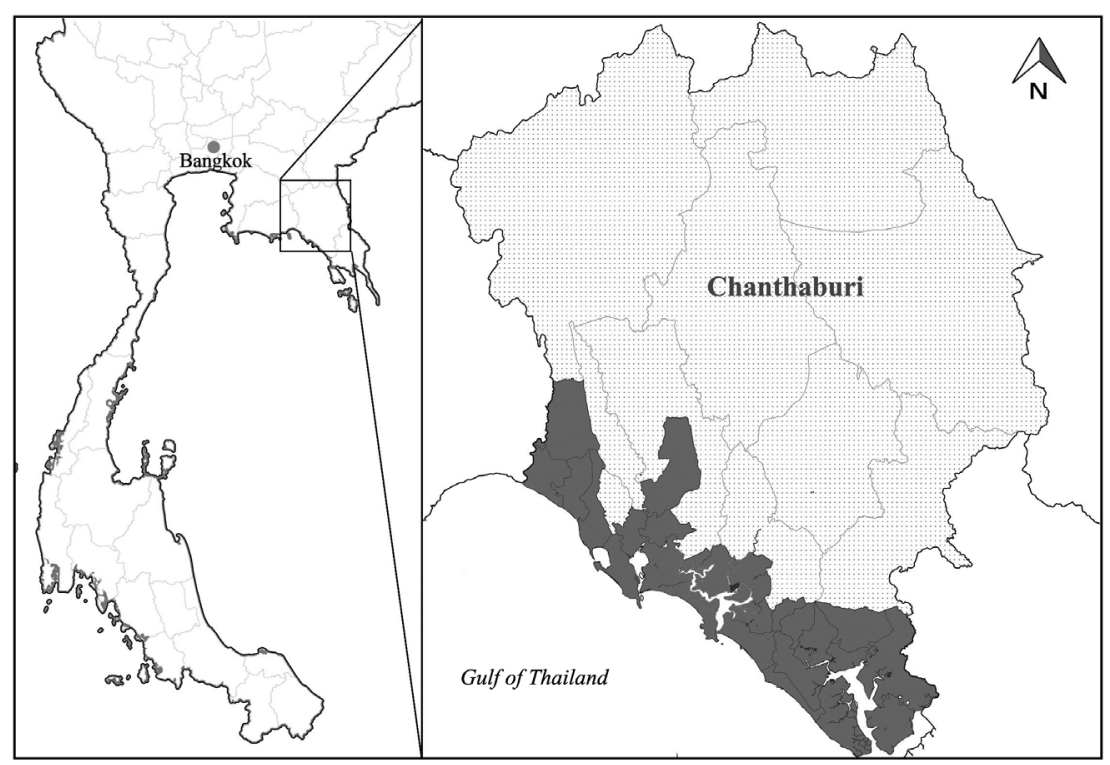

Fig. 1. Location of the study area, Chanthaburi province $\left(12.6103^{\circ} \mathrm{N}, 102.1028^{\circ} \mathrm{E}\right)$, Thailand. The shrimp farming zone is indicated by shading 


\section{Statistical analysis}

All statistical procedures were performed using SPSS version 22.0 (IBM). The negative binomial regression (NBR) model was used to estimate the association between monthly WSD occurrence (count, dependent variable) and climate factors from January 2009 to December 2014 (independent variables). Continuous-scale variables were transformed to a categorical scale using quartiles when the distribution did not show normality or linearity. Univariate analysis was performed, and variables that were statistically significant at the $85 \%$ confidence intervals were included in the multivariate model. Collinearity between significant variables was examined using Spearman's rank correlations, and correlation coefficients $(r)$ greater than 0.40 were interpreted as an indication of collinearity. Selection of collinear variables included in the final multivariate model was based on significant $p$-values $(<0.05)$ of the final model and acceptability of potential biological cause-effect relationships. Incident rate ratios (IRR) and their 95\% confidence intervals $(95 \% \mathrm{CI})$ were calculated for statistically significant variables. Interactions among variables in the final constructed model were examined. If no interaction was found, factors that would change the regression coefficient estimates of at least one other factor by more than $25 \%$ were considered to be confounders and subsequently included in the final model to adjust the confounding effect of those variables.

\section{RESULTS}

\section{WSD occurrence}

A total of 1952 WSD cases were reported during the study period (January 2009 to December 2014). The cases were from different shrimp stages; 9-30 d of culture (1106 cases), 31-60 d of culture (618 cases), 61-90 d of culture (202 cases) and 91-119 d of culture (26 cases). Annual WSD prevalence and the number of WSD cases ranged from a high of $61.79 \%$ and 482 cases (in 2011) to a low of $12.09 \%$ and 210 cases (in 2014). Patterns of WSD prevalence and number of cases between 2009 and 2014 were variable between seasons, with a high prevalence of cases reported from October to February. A decrease in WSD prevalence and cases were observed from March to June, with the lowest WSD prevalence reported in May (Table 1).

\section{Climate factors associated with WSD occurrence}

Observed data of all climate factors except daily temperature variation were not normally distributed; therefore, they were divided into 4 groups using quartile rank. Univariate NBR analysis showed significant association between WSD occurrence and all climate factors (Table 2). Spearman's correlation showed positive correlations among the atmospheric temperature factors and rainfall factors. Average wind

Table 1. White spot disease (WSD) prevalence (\%) and number of WSD cases reported from 2009 to 2014 in Chanthaburi province, Thailand

\begin{tabular}{|llccccc}
\hline \multirow{2}{*}{ Month } & & \multicolumn{5}{c}{ Prevalence (positive cases/total submitted cases) } \\
& \multicolumn{1}{c}{2009} & 2010 & 2011 & 2012 & 2013 \\
\hline January & $63.16(24 / 38)$ & $66.67(32 / 48)$ & $89.47(34 / 38)$ & $66.67(52 / 78)$ & $22.64(24 / 106)$ & $16.10(18 / 112)$ \\
February & $58.62(34 / 58)$ & $58.70(54 / 92)$ & $69.44(50 / 72)$ & $54.76(46 / 84)$ & $25.00(26 / 104)$ & $25.50(28 / 110)$ \\
March & $39.29(22 / 56)$ & $32.56(28 / 86)$ & $68.42(52 / 76)$ & $44.00(44 / 100)$ & $14.29(18 / 126)$ & $5.80(8 / 138)$ \\
April & $32.14(18 / 56)$ & $29.17(14 / 48)$ & $51.85(28 / 54)$ & $40.00(16 / 40)$ & $8.54(14 / 164)$ & $5.90(10 / 170)$ \\
May & $41.67(10 / 24)$ & $6.67(2 / 30)$ & $28.57(12 / 42)$ & $17.86(10 / 56)$ & $4.55(6 / 132)$ & $11.10(16 / 144)$ \\
June & $35.29(24 / 68)$ & $33.33(10 / 30)$ & $40.00(20 / 50)$ & $21.88(14 / 64)$ & $5.15(10 / 194)$ & $4.00(8 / 200)$ \\
July & $31.25(20 / 64)$ & $17.65(6 / 34)$ & $55.56(30 / 54)$ & $23.21(26 / 112)$ & $7.92(16 / 202)$ & $7.40(16 / 216)$ \\
August & $50.00(36 / 72)$ & $50.00(30 / 60)$ & $51.85(56 / 108)$ & $20.41(20 / 98)$ & $17.65(24 / 136)$ & $8.00(12 / 150)$ \\
September & $30.77(8 / 26)$ & $26.09(12 / 46)$ & $72.73(48 / 66)$ & $30.43(28 / 92)$ & $6.82(6 / 88)$ & $10.20(10 / 98)$ \\
October & $67.92(72 / 106)$ & $68.97(40 / 58)$ & $68.89(62 / 910)$ & $20.18(44 / 218)$ & $28.57(32 / 112)$ & $11.30(14 / 124)$ \\
November & $42.86(24 / 56)$ & $80.65(50 / 62)$ & $65.85(54 / 82)$ & $27.78(40 / 144)$ & $26.67(32 / 120)$ & $16.70(22 / 132)$ \\
December & $78.95(30 / 38)$ & $95.24(40 / 42)$ & $75.00(36 / 48)$ & $46.67(28 / 60)$ & $34.38(44 / 128)$ & $33.80(48 / 142)$ \\
Annual prevalence & $48.64(322 / 662)$ & $50.00(318 / 636)$ & $61.79(482 / 780)$ & $32.11(368 / 1146)$ & $15.63(252 / 1612)$ & $12.09(210 / 1736)$ \\
& & & & & \\
\hline
\end{tabular}


Table 2. Univariate negative binomial regression model for the association between monthly white spot disease (WSD) occurrence and climate factors; estimated coefficient $(\beta)$, incident rate ratio (IRR) and 95\% confidence intervals (95\% CI), and the quasi-likelihood independence model criterion (QIC). The fourth quartile of each factor was used as reference

\begin{tabular}{|c|c|c|c|c|}
\hline Factor & $\beta$ & IRR (95\% CI) & p-value & QIC \\
\hline \multicolumn{5}{|l|}{ Atmospheric temperature $\left({ }^{\circ} \mathrm{C}\right)$} \\
\hline Average & & & $<0.0001$ & 31.27 \\
\hline Quartile 1 (24.5-27.2) & 0.99 & $2.71(1.86-3.95)$ & & \\
\hline Quartile 2 (27.3-27.9) & 0.62 & $1.86(1.21-2.86)$ & & \\
\hline Quartile 3 (28.0-28.5) & 0.55 & $1.74(2.16-2.58)$ & & \\
\hline Quartile 4 (28.6-29.8) & & - & & \\
\hline Minimal average & & & $<0.0001$ & 31.99 \\
\hline Quartile 1 (19.7-23.8) & 0.88 & $2.41(1.68-3.46)$ & & \\
\hline Quartile 2 (23.9-24.7) & 0.55 & $1.73(1.18-2.56)$ & & \\
\hline Quartile 3 (24.8-25.8) & 0.09 & $1.10(0.68-1.77)$ & & \\
\hline Quartile 4 (25.9-26.2) & & - & & \\
\hline Maximal average & & & 0.07 & 38.45 \\
\hline Quartile 1 (29.9-31.7) & 0.45 & $1.57(1.01-2.41)$ & & \\
\hline Quartile 2 (31.8-32.5) & 0.3 & $1.35(0.83-2.18)$ & & \\
\hline Quartile 3 (32.6-33.3) & 0.55 & $1.73(1.13-2.65)$ & & \\
\hline Quartile 4 (33.4-34.8) & & - & & \\
\hline Daily variation & & & 0.03 & 35.57 \\
\hline $8.2 \pm 1.4($ mean $\pm \mathrm{SD})$ & 0.11 & $1.12(1.01-1.25)$ & & \\
\hline \multicolumn{5}{|l|}{ Rainfall } \\
\hline Total amount (mm) & & & 0.01 & 36.23 \\
\hline Quartile 1 (0-54.5) & 0.64 & $1.90(1.28-2.81)$ & & \\
\hline Quartile 2 (54.6-190.1) & 0.07 & $1.08(0.69-1.68)$ & & \\
\hline Quartile 3 (190.2-411.5) & 0.16 & $1.18(0.76-1.81)$ & & \\
\hline Quartile 4 (411.6-1035.4) & & - & & \\
\hline Number of rain days & & & 0.05 & 38.1 \\
\hline Quartile $1(0-6)$ & 0.52 & $1.67(1.12-2.51)$ & & \\
\hline Quartile 2 (6-16) & 0.3 & $1.35(0.92-2.00)$ & & \\
\hline Quartile 3 (17-24) & 0.81 & $1.08(0.70-1.68)$ & & \\
\hline Quartile $4(>28)$ & & - & & \\
\hline Average relative humidity (\%) & & & $<0.0001$ & 37.57 \\
\hline Quartile 1 (57.0-74.3) & 0.69 & $2.00(1.32-3.04)$ & & \\
\hline Quartile 2 (74.4-80.5) & 0.16 & $1.17(0.74-1.85)$ & & \\
\hline Quartile 3 (80.6-84.0) & 0.16 & $1.17(0.75-1.83)$ & & \\
\hline Quartile 4 (84.1-88.0) & & - & & \\
\hline Average wind speed (knots) & & & 0.02 & 36.13 \\
\hline Quartile 1 (0.90-1.30) & -0.63 & $0.53(0.37-0.78)$ & & \\
\hline Quartile 2 (1.40-1.60) & -0.59 & $0.55(0.38-0.81)$ & & \\
\hline Quartile 3 (1.70-2.10) & -0.27 & $0.76(0.53-1.11)$ & & \\
\hline Quartile 4 (2.11-4.50) & & - & & \\
\hline
\end{tabular}

the final model, average atmospheric temperature (IRR: 2.53, $95 \%$ CI: 1.72-3.75) and daily atmospheric temperature variation (IRR: 1.08, 95\% CI: 0.97-1.20) (Table 4). Interaction and confounding among the factors in the final model were not observed. The multivariate NBR model indicated that WSD occurrence increased with decreasing atmospheric temperature, and the highest WSD occurrence was found at an atmospheric temperature between 24.5 and $27.2^{\circ} \mathrm{C}$. The variation of daily atmospheric temperature $>10^{\circ} \mathrm{C}$ also substantially raised the incidence of disease. Fig. 2 illustrates the relationship between WSD occurrence and the significant climate factors.

\section{DISCUSSION}

This study indicates a significant influence of atmospheric temperature on the occurrence of WSD in Chanthaburi province, Thailand. WSD cases were reported in many stages of shrimp post-larvae, from 9 to $119 \mathrm{~d}$ culture. Higher WSD incidence was found within the first 2 mo of stocking. Despite the notable susceptibility to WSD in younger stages of shrimp, exposure to the same climate conditions resulted in the same WSD occurrence in various stages from juvenile to adult shrimp (see Table S1 and Fig. S1 in the supplement at www.int-res.com/ articles/suppl/q008p331_supp.pdf). A high number of WSD cases in this speed correlated negatively with atmospheric temperature and rainfall. In addition, significant negative correlation ( $r=-0.81)$ was found between daily atmospheric temperature variation and total amount of rainfall (Table 3). Because of their negative correlation, both factors could not be concurrently introduced into the multivariate model. The final multivariate NBR model was constructed based on the smallest quasi-likelihood independence model criterion (QIC) value (smaller values indicate a better fit of a model). Consequently, 2 factors were selected for study were observed during months with relatively low atmospheric temperature $\left(<27.2^{\circ} \mathrm{C}\right)$ and a high degree of daily atmospheric temperature variation $\left(>10^{\circ} \mathrm{C}\right)$. Multivariate analysis indicated that incident rate of WSD increased gradually when atmospheric temperature decreased (Table 4). It was evident that WSD cases occurred 2.53 times more in months with an average atmospheric temperature of 24.5 to $27.2^{\circ} \mathrm{C}$ than those in months with an average atmospheric temperature of 28.6 to $29.8^{\circ} \mathrm{C}$. Atmospheric temperature is positively correlated to pond-water 
Table 3. Spearman's correlation among significant factors; correlation coefficients. Significance: ${ }^{* * *} \mathrm{p}<0.0001,{ }^{* *} \mathrm{p}<0.01,{ }^{*} \mathrm{p}<0.05$

\begin{tabular}{|c|c|c|c|c|c|c|c|}
\hline \multirow[t]{2}{*}{ Factor } & \multicolumn{2}{|c|}{ Atmospheric temperature } & \multicolumn{3}{|c|}{-Rainfall } & \multirow{2}{*}{$\begin{array}{l}\text { Average } \\
\text { relative } \\
\text { humidity }\end{array}$} & \multirow{2}{*}{$\begin{array}{c}\text { Average } \\
\text { wind } \\
\text { speed }\end{array}$} \\
\hline & $\begin{array}{l}\text { Minimal } \\
\text { average }\end{array}$ & $\begin{array}{l}\text { Maximal } \\
\text { average }\end{array}$ & $\begin{array}{c}\text { Daily } \\
\text { variation }\end{array}$ & $\begin{array}{c}\text { Total } \\
\text { amount }\end{array}$ & $\begin{array}{l}\text { Rain } \\
\text { days }\end{array}$ & & \\
\hline \multicolumn{8}{|l|}{ Atmospheric temperature } \\
\hline Average & $0.72^{* * *}$ & $0.58^{* * *}$ & -0.19 & $0.25^{*}$ & 0.18 & 0.12 & $-0.45^{*}$ \\
\hline Minimal average & - & $0.12^{*}$ & $-0.64^{* * *}$ & $0.65^{* * *}$ & $0.59^{* * *}$ & $0.56^{* * *}$ & $-0.43^{* * *}$ \\
\hline Maximal average & - & - & $0.50^{* * *}$ & $-0.33^{* *}$ & $-0.35^{* *}$ & $-0.40^{* *}$ & -0.12 \\
\hline Daily variation & - & - & - & $-0.81^{* * *}$ & $-0.79^{* * *}$ & $-0.82^{* * *}$ & $0.36^{*}$ \\
\hline \multicolumn{8}{|l|}{ Rainfall } \\
\hline Total amount & - & - & - & - & $0.88^{* * *}$ & $0.80^{* * *}$ & $-0.43^{* * *}$ \\
\hline Rain days & - & - & - & - & - & $0.80^{* * *}$ & $-0.46^{* * *}$ \\
\hline Average relative humidity & - & - & - & - & - & - & $-0.65^{* * *}$ \\
\hline
\end{tabular}

temperature (Nargis \& Pramanik 2008), and decreased water temperature has been reported as an important factor that supports viral replication but adversely affects shrimp immune response (Xue et al. 2015). Experimental infection of WSSV in L. vannamei at a water temperature 27 to $30^{\circ} \mathrm{C}$ resulted in the development of WSD gross signs, the presence of WSSV-infected cells and a 100\% mortality rate, while none of these outcomes were found in a similar experiment at $33^{\circ} \mathrm{C}$ (Rahman et al. 2006). WSSV gene expression in subcuticular epithelial cells was higher at water temperature of $26^{\circ} \mathrm{C}$ compared with $33^{\circ} \mathrm{C}$ (Reyes et al. 2007). WSSV proliferation in Chinese white shrimp Fenneropenaeus chinensis evaluated using real-time PCR indicated that the optimum temperature for WSSV proliferation was $25^{\circ} \mathrm{C}$ (Gao et al. 2011). A crucial shrimp defense mechanism such as WSSV-induced apoptosis was found to decrease at a water temperature below $32^{\circ} \mathrm{C}$ (Granja et al. 2003). In addition, higher mortality rates were observed in $P$. monodon orally challenged with WSSV at water temperatures ranging from 16 to $30^{\circ} \mathrm{C}$ than those challenged at 32 to $36^{\circ} \mathrm{C}$ (Raj et al. 2012).

The statistical model of the observed data revealed that an increase of daily atmospheric temperature variation of $1^{\circ} \mathrm{C}$ raised the rate of WSD occurrence by $8 \%$ (IRR: 1.08 ; Table 4). The temperature change within a day usually affects the fluctuation of water temperature, and this condition was shown to induce WSD outbreaks with a low level of WSSV infection in cultured shrimp (Hsu et al. 2000, Kautsky et al. 2000). Fluctuation of 3 to $4^{\circ} \mathrm{C}$ in water temperature during a day was shown to activate WSD outbreaks in cultured $P$. monodon in the Philippines (Tendencia \& Verreth 2011). The impairment of immune function, a decrease in total haemocyte count, phenoloxidase and nitric oxide synthase activity, as well as a high rate of lipid peroxidation activity, which was indicated by the increase in malondialdehyde, were observed in L. vannamei during a sudden drop (22 to $16^{\circ} \mathrm{C}$ ) in water temperature (Jia et al. 2014). An earlier study suggested that high amount of rain induced WSD occurrence due to the change in water temperature and salinity (Peinado-Guevara \& López-Meyer 2006); however, our study found lower WSD occurrence during months with a high amount of rain. The majority (98\%) of data was from L. vannamei, the main cultured species in Thailand. This euryhaline shrimp tolerates a wide range of salinity, 1-40\% (Lin et al. 2012), thus the change in salinity during a period of high rainfall was presumably irrelevant to WSD occurrence in this shrimp species. Besides, less atmospheric temperature fluctuation in months with a high amount of rain $(r=-0.81$; Table 3$)$ and the

Table 4. Multivariate negative bionomial regression model for the association between monthly white spot disease occurrence and climate factors; estimated coefficient ( $\beta$ ), incident rate ratio (IRR) and $95 \%$ confidence intervals (95\% CI).

The fourth quartile of each factor was used as reference

\begin{tabular}{|lccc|}
\hline Factor & $\beta$ & IRR $(95 \%$ CI $)$ & p-value \\
\hline Constant & -1.56 & & \\
Average atmospheric temperature $\left({ }^{\circ} \mathrm{C}\right)$ & & & $<0.0001$ \\
Quartile 1 $(24.5-27.2)$ & 0.93 & $2.53(1.72-3.75)$ & \\
Quartile 2 $(27.3-27.9)$ & 0.64 & $1.91(1.25-2.92)$ & \\
Quartile 3 $(28.0-28.5)$ & 0.55 & $1.74(1.12-2.59)$ & \\
Quartile 4 (28.6-29.8) & & - & 0.07 \\
Daily atmospheric temperature variation & & & \\
8.2 + 1.4 (mean + SD) & 0.08 & $1.08(0.99-1.20)$ & \\
\hline
\end{tabular}




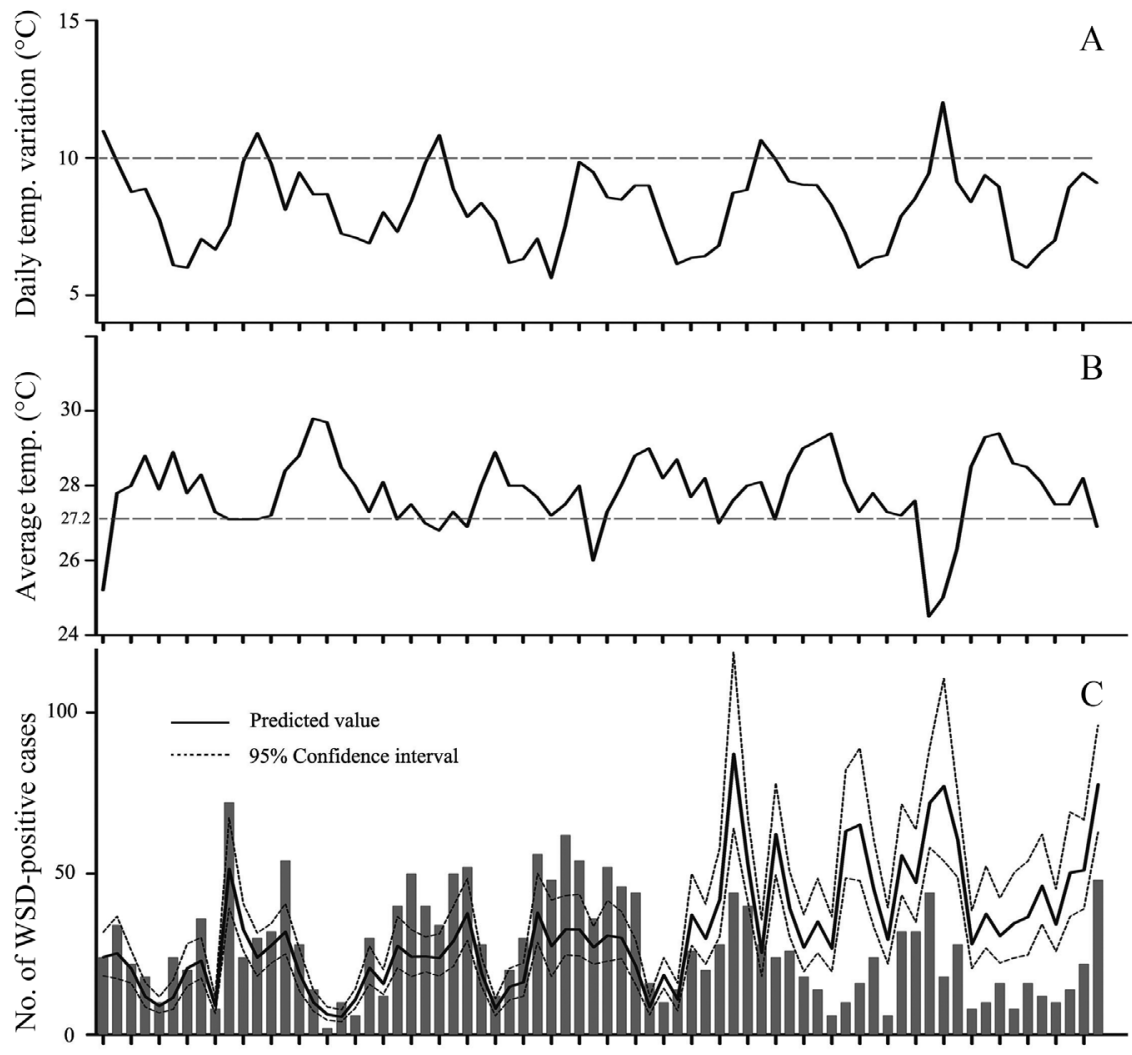

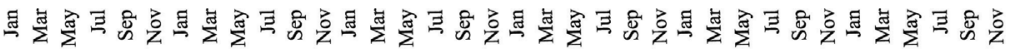

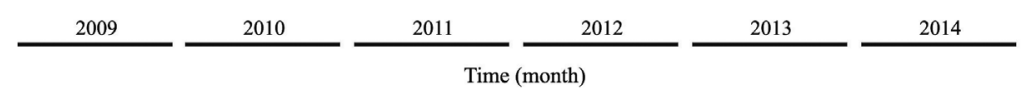

Fig. 2. Climate factors significantly associated with white spot disease (WSD) occurrence in Chanthaburi province, Thailand. (A) Daily atmospheric temperature variation, (B) average atmospheric temperature and (C) number of WSDpositive cases. The predicted values obtained from the multivariate negative binomial regression model are presented against the observed values (bars) in (C)

moderate minimum water temperature in rainy months may contribute to lower WSD occurrence. It was also reported that cloud accumulation during a rainy period in the Philippines slowed the cooling process of pond water during the night, and subsequently resulted in a higher average minimum water temperature in the shrimp pond (Tendencia et al. 2010).

The highest number of WSD occurrence (482 cases) was observed in the year 2011 (Table 1). It should be noted that the weather in the Asia-Pacific region in mid-2010 to early 2011 was strongly impacted by the La Niña event. This phenomenon also caused an unusual decrease in atmospheric temperature during the cool season in Thailand in 2011 (Fig. 2) (Ueangsawat \& Jintrawet 2013). La Niña was also believed to be a cause of high WSD prevalence in Ecuador in 1999 due to a lower atmospheric temperature than normal (Rodríguez et al. 2003). The present survey provided another example of the effect of climate change on an infectious disease in a marine organism.

A dramatic decline of WSD prevalence from 2012 to 2014 was observed in the present study. An emergence of the early mortality syndrome (EMS), now known as acute hepatopancreatic necrosis disease (AHPND), has attacked shrimp culture in this area since late 2011. EMS/AHPND was present in most of the samples analyzed, and this may have masked the decrease in WSD prevalence as it was calculated based on the ratio of WSSV PCR-positive samples to total number of samples analyzed. In addition to the sudden prevalence of EMS/AHPND that caused mass mortality in early stocking post-larvae, shrimp farmers in this area decreased their operations. Shrimp cultured areas and production yield of Chanthaburi province decreased by over $40 \%$ in 2014 compared with 2011 (Department of Fisheries 2014). This also explains the marked deviation of the predicted values in the multivariate NBR model, while the predicted values during 2009 to 2011 corresponded to observed values. Despite the deviated prevalence, the number of WSD cases remained the same, and the influence of climate factors was still apparent in the area. The emergence of a new disease may affect the prevalence of endemic WSD; however, this study's findings suggest that WSD is still a major constraint in this shrimp farming community, especially when temperatures are low and fluctuate.

The results of the present study suggest that the occurrence of WSD in shrimp culture communities in Chanthaburi province, Thailand, is more prevalent during October to February. The occurrence of WSD is significantly related to low atmospheric temperature and a high degree of daily temperature variation. In contrast to reports in Mexico and the Philippines, this study found that the effect of rain was not an important influence of WSD occurrence in this area. Because WSD prevalence evidently differs among geographical locations and culture systems, investigations of disease prevalence should be implemented specifically to accommodate dissimilarities in shrimp culture conditions. Although our results present a correlation between climate and WSD 
occurrence for a specific region, we were not able to address the effect of combined infection that potentially developed in WSD cases. It should be noted that WSD often occurs with Vibrio infections (Tendencia \& Verreth 2011, Jang et al. 2014), and such a situation may impose the disease occurrence conditions.

Acknowledgements. The authors thank the Chanthaburi Coastal Fisheries Research and Development Centre for providing data for this study. This work was supported by the University Graduate Scholarship to Commemorate the 72nd Anniversary of His Majesty King Bhumibol Adulyadej; the 90th Anniversary University Ratchadaphiseksomphot Endowment Fund; Overseas Research Experience Scholarship for Graduate Students; and the Special Task Force for Activating Research, Chulalongkorn University.

\section{LITERATURE CITED}

de la Peña LD, Lavilla-Pitogo CR, Villar CBR, Paner MG, Sombito CD, Capulos GC (2007) Prevalence of white spot syndrome virus (WSSV) in wild shrimp Penaeus monodon in the Philippines. Dis Aquat Org 77:175-179

Department of Fisheries (2014) Fisheries statistic. Dept of Fisheries, Ministry of Agriculture, Bangkok. www. fisheries.go.th/it-stat/ (accessed 5 March 2015)

Flegel TW (1997) Major viral diseases of the black tiger prawn (Penaeus monodon) in Thailand. World J Microbiol Biotechnol 13:433-442

Flegel TW (2012) Historic emergence, impact and current status of shrimp pathogens in Asia. J Invertebr Pathol 110:166-173

Gao H, Kong J, Li Z, Xiao G, Meng X (2011) Quantitative analysis of temperature, salinity and $\mathrm{pH}$ on WSSV proliferation in Chinese shrimp Fenneropenaeus chinensis by real-time PCR. Aquaculture 312:26-31

- Granja CB, Aranguren LF, Vidal OM, Aragon L, Salazar M (2003) Does hyperthermia increase apoptosis in white spot syndrome virus (WSSV)-infected Litopenaeus vannamei? Dis Aquat Org 54:73-78

Hossain A, Nandi SP, Siddique MA, Sanyal SK, Sultana M, Hossain MA (2015) Prevalence and distribution of white spot syndrome virus in cultured shrimp. Lett Appl Microbiol 60:128-134

Hsu HC, Lo CF, Chiu YL, Chang CF, Kou GH (2000) Effect of temperature shifts on shrimp lightly infected with white spot syndrome virus (WSSV). Acta Zool Taiwanica 11:63-81

Iqbal M, Kabir M, Alan C, Mamun M, Hossain M (2011) Seasonal status of white spot syndrome virus in broodstocks, nauplii and postlarvae of black tiger shrimp (Penaeus monodon) in Bangladesh. Int J Nat Sci 1:56-61

> Jang IK, Qiao G, Kim SK (2014) Effect of multiple infections with white spot syndrome virus (WSSV) and Vibrio anguillarum on Pacific white shrimp, Litopenaeus vannamei (L.): mortality and viral replication. J Fish Dis 37: 911-920

Jia X, Wang F, Lu Y, Zhang D, Dong S (2014) Immune responses of Litopenaeus vannamei to thermal stress: a comparative study of shrimp in freshwater and seawater conditions. Mar Freshwat Behav Physiol 47:79-92

Kautsky N, Rönnbäck P, Tedengren M, Troell M (2000) Ecosystem perspectives on management of disease in shrimp pond farming. Aquaculture 191:145-161

> Lin YC, Chen JC, Li CC, Morni WZW and others (2012) Modulation of the innate immune system in white shrimp Litopenaeus vannamei following long-term low salinity exposure. Fish Shellfish Immunol 33:324-331

Nargis A, Pramanik S (2008) Physico-chemical parameters in relation to meteorological and climatic conditions in a fish pond. Bangladesh J Sci Ind Res 43:405-410

OIE (World Organization for Animal Health) (2015) White spot disease. Manual of diagnostic tests for aquatic animals 2015, chapter 2.2.6. www.oie.int/internationalstandard-setting/aquatic-manual/access-online/ (accessed 15 May 2015)

> Peinado-Guevara LI, López-Meyer M (2006) Detailed monitoring of white spot syndrome virus (WSSV) in shrimp commercial ponds in Sinaloa, Mexico by nested PCR. Aquaculture 251:33-45

Rahman M, Escobedo-Bonilla C, Corteel M, Dantas-Lima J and others (2006) Effect of high water temperature $\left(33^{\circ} \mathrm{C}\right)$ on the clinical and virological outcome of experimental infections with white spot syndrome virus (WSSV) in specific pathogen-free (SPF) Litopenaeus vannamei. Aquaculture 261:842-849

Raj S, Vijayan KK, Alavandi SV, Balasubramanian CP, Santiago TC (2012) Effect of temperature and salinity on the infectivity pattern of white spot syndrome virus (WSSV) in giant tiger shrimp Penaeus monodon (Fabricius, 1837). Indian J Fish 59:109-115

Reyes A, Salazar M, Granja C (2007) Temperature modifies gene expression in subcuticular epithelial cells of white spot syndrome virus-infected Litopenaeus vannamei. Dev Comp Immunol 31:23-29

Rodríguez J, Bayot B, Amano Y, Panchana F, De Blas I, Alday V, Calderón J (2003) White spot syndrome virus infection in cultured Penaeus vannamei (Boone) in Ecuador with emphasis on histopathology and ultrastructure. J Fish Dis 26:439-450

Tendencia EA, Verreth JAJ (2011) Temperature fluctuation, low salinity, water microflora: risk factors for WSSV outbreaks in Penaeus monodon. Isr J Aquacult-Bamid 63:1-7

Tendencia EA, Bosma RH, Usero RC, Verreth JAJ (2010) Effect of rainfall and atmospheric temperature on the prevalence of the white spot syndrome virus in pondcultured Penaeus monodon. Aquacult Res 41:594-597

Ueangsawat K, Jintrawet A (2013) The impacts of ENSO phases on the variation of rainfall and streamflow in the Upper Ping River Basin, Northern Thailand. Environ Nat Resour J 11:97-119

van Hulten MCW, Witteveldt J, Peters S, Kloosterboer N and others (2001) The white spot syndrome virus DNA genome sequence. Virology 286:7-22

Withyachumnarnkul B, Boonsaeng V, Chomsoong R, Flegel TW, Muangsin S, Nash GL (2003) Seasonal variation in white spot syndrome virus-positive samples in broodstock and post-larvae of Penaeus monodon in Thailand. Dis Aquat Org 53:167-171

Xue S, Wei J, Li J, Geng X, Sun J (2015) Effects of total ammonia, temperature and salinity on the mortality and viral replication of WSSV-infected Chinese shrimp (Fenneropenaeus chinensis). Aquac Res doi:10.111/are. 12877

Submitted: December 2, 2015; Accepted: March 3, 2016

Proofs received from author(s): April 13, 2016 